\title{
Activation of Protein Kinase C (PKC) by 3,4- Methylenedioxymethamphetamine (MDMA) Occurs Through the Stimulation of Serotonin Receptors and Transporter
}

\author{
H. Kenneth Kramer, M.D., Ph.D., Jose C. Poblete, Ph.D., and Efrain C. Azmitia, Ph.D.
}

This report further characterizes the intermediate metabolic effects of the psychotropic amphetamine derivative, 3,4methylenedioxymethamphetamine (MDMA or "ecstasy"), on the activity of second messenger-dependent kinases. Previous work has demonstrated that two injections of MDMA (20 mg/kg) elicits a prolonged translocation of the calcium and phospholipid-dependent enzyme, protein kinase C (PKC) in rats. However, because MDMA has actions at the $5-\mathrm{HT}$ transporter and $5-\mathrm{HT}_{2 \mathrm{~A} / 2 \mathrm{C}}$ receptors, our experiments were directed at uncovering which of these many sites may be involved in this second messengerdependent response. A single injection of MDMA produced a time- and dose-dependent increase in the density of cortical and hippocampal PKC (as measured by ${ }^{3} \mathrm{H}$-phorbol 12,13-dibutyrate $(P D B u)$ ) binding sites. MDMA-mediated $P K C$ translocation was long-lasting and remained above control (saline-treated rats) for up to 24 h after injection. This effect was mimicked by another substituted amphetamine, $p$-chloroamphetamine ( $p C A)$, but with a temporal-response curve that was to the left of MDMA's.
However, pure uptake inhibitors like fluoxetine, cocaine, and the selective 5-HT ${ }_{2 \mathrm{~A} / 2 \mathrm{C}}$ agonist, $\mathrm{DOB}$, were unable to produce a long-lasting translocation of PKC binding sites in rat cortex. Fluoxetine, a selective serotonin uptake inhibitor (SSRI) and ketanserin, a 5-HT ${ }_{2 A}$ antagonist, attenuated PKC translocation by MDMA with differing efficacies; however, both compounds completely prevented the loss of 5-HT uptake sties after multiple doses of $M D M A$. These results suggest that MDMA increases PKC translocation by two interrelated mechanisms that involve $5-\mathrm{HT}_{2 \mathrm{~A} / 2 \mathrm{C}}$ receptors and the $5-\mathrm{HT}$ transporter. This pathway appears to include: (1) the drug binding to the 5-HT transporter, (2) the release of cytosolic 5-HT stores into the extracellular space, and (3) the activation of post-synaptic 5-HT $2 \mathrm{~A} / 2 \mathrm{C}$ receptors linked to G-proteinmediated phospholipid hydrolysis.

[Neuropsychopharmacology 17:117-129, 1997]

(C) 1997 American College of Neuropsychopharmacology. Published by Elsevier Science Inc.
KEY WORDS: Serotonin; Transporter; Second messenger; Calcium; Serotonin $2 \mathrm{~A} / 2 \mathrm{C}$

From the Department of Psychiatry (HKK), New York University Medical Center and Department of Biology (JCP, ECA), New York University, New York, New York.

Address correspondence to: H. Kenneth Kramer, M.D., Ph.D., Department of Psychiatry, New York University Medical Center, Room THN-610, 550 First Avenue, New York, NY 10016.

Received October 30, 1996; revised February 5, 1997; accepted February 10, 1997.
MDMA is part of a class of amphetamine derivatives (including para-chloroamphetamine (pCA) and fenfluramine (FEN)) whose acute psychoactive and long-term neurotoxic effects appear to be dependent on their ability to promote a calcium-independent release of 5-HT from presynaptic nerve terminals (Sanders-Bush and Strenaka 1978; Nichols et al. 1982; Schmidt 1987; O'Hearn et al. 1988; Appel et al. 1989; Schmidt et al. 1990; Berger et al. 1992a,b). MDMA shows a unique selectivity for the serotonergic system through its efficacy 
for releasing 5-HT, inhibiting its reuptake, and producing the degeneration of presynaptic serotonergic elements (Johnson et al. 1986; Schmidt 1987; Commins et al. 1987; Battaglia et al. 1988; O'Hearn et al. 1988; Ricaurte et al. 1988; Insel et al. 1989; Fischer et al. 1995). However, the intermediate metabolic changes that occur and ultimately result in 5-HT fiber loss have not been investigated thoroughly (for a review, see Steele et al. 1994).

Among its many pharmacological characteristics, MDMA has been reported to influence intracellular calcium dynamics. Acutely, MDMA induces a concentration-dependent increase in calcium uptake into cortical synaptosomes (Park and Azmitia 1991; Azmitia et al. 1993). Furthermore, long-term reductions in 5-HT biomarkers, as well as changes in astrocyte responses, are attenuated by MK- 801 and nimodipine-antagonists for the NMDA-sensitive $\mathrm{Ca}^{2+}$ channel and the L-type $\mathrm{Ca}^{2+}$ channel, respectively-supporting the existence of a calcium-dependent component in MDMA's long-term effects (Azmitia 1989; Azmitia et al. 1990; Farfel et al. 1992; Pu and Vorhees 1995). These observations suggest that calcium-dependent second messenger systems could be involved in the development of MDMA-mediated serotonergic neurodegeneration. One such pathway may involve the calcium-activated and phospholipid-dependent enzyme, protein kinase C (PKC) (Berridge 1984; Nishizuka 1986). PKC is abundant in 5-HT neurons, surrounding glial cells, and is activated in both cell types through stimulation of the $5-\mathrm{HT}_{2 \mathrm{~A} / 2 \mathrm{C}}$ receptor (Conn and Sanders-Bush 1985, 1986; Wang and Friedman 1990; Kagaya et al. 1990; Masliah et al. 1991; Gott et al. 1994).

Numerous experiments have shown that several of MDMAs'acute (hyperthermia and dopamine release) and neurotoxic effects arise through interactions with the central 5- $\mathrm{HT}_{2 \mathrm{~A} / 2 \mathrm{C}}$ receptor (Schmidt et al. 1991; Malberg et al. 1994; Poblete and Azmitia 1995). These findings are consistent with MDMA's agonist-like properties at the $5-\mathrm{HT}_{2 \mathrm{~A} / 2 \mathrm{C}}$ receptor, which include the potentiation of DA release and the acceleration of glycogenolysis in astrocytes (Nash 1990; Poblete and Azmitia 1995). Pretreatment of primary cultured serotonergic neurons with the $5-\mathrm{HT}_{2 \mathrm{~A}}$ antagonist, ketanserin, reduces their susceptibility to toxic concentrations of MDMA (Azmitia et al. 1990). In vivo, Schmidt et al. (1990) have shown that hyperthermia and long-term reductions in cortical, hippocampal, and striatal 5-HT content are competitively reversed by pretreatment with the $5-\mathrm{HT}_{2 \mathrm{~A} / 2 \mathrm{C}}$ antagonist, MDL 11,939.

In vitro, activation of the $5-\mathrm{HT}_{2 \mathrm{~A} / 2 \mathrm{C}}$ receptor begins the G-protein-linked hydrolysis of phosphotidylinositol 4,5-bisphosphate $\left(\mathrm{PIP}_{2}\right)$, which liberates diacylglycerol (DAG) and inositol 1,4,5-trisphosphate ( $\mathrm{IP}_{3}$ ) (Conn and Sanders-Bush 1985, 1986; Kendall and Nahorski 1985; Nishizuka 1986). Inositol trisphosphate stimulates the release of calcium from intracellular stores, which ulti- mately increases $\left[\mathrm{Ca}^{2+}\right]_{\mathrm{i}}$ concentration (Kendall and Nahorski 1985). Both of these metabolic intermediates contribute to the translocation of PKC to the plasma membrane (Berridge 1984; Nishizuka 1986; Manev et al. 1990). Under basal conditions, PKC exists inactively as a soluble cytosolic enzyme but becomes translocated to the plasma membrane (in its active form) upon receptor stimulation by hormones, neurotransmitters, or directly by tumor-promoting phorbol esters (Castanga et al. 1982; Wolf et al. 1985). The translocation of PKC is believed to be the primary process by which it becomes biologically active (Favaron et al. 1988).

It is known that MDMA's parent compound, amphetamine, which promotes the release of dopamine (DA) from rat brain synaptosomes, has been shown to increase PKC translocation and activity in vivo and within synaptosomes (Giambalvo 1992a,b). We have previously reported that multiple injections of MDMA produce a long-term translocation of PKC to rat cortical membranes; however the localization (either pre or postsynaptic) of the MDMA-sensitive PKC pool remained undefined (Kramer and Azmitia 1994; Kramer et al. 1995). Since the prolonged translocation of PKC has been implicated in several calcium-dependent neurodengenerative processes including ischemia (Manev et al. 1990), its possible role in MDMA-induced neurotoxicity is currently under investigation. MDMA, which itself produces a $5-\mathrm{HT}_{2 \mathrm{~A} / 2 \mathrm{C}}$ receptor and $\mathrm{Ca}^{2+}$-dependent form of neurotoxicity, may require the activation of PKC. In this report, we extend the findings of our previous study to conclude that MDMA produces PKC translocation through two separate mechanisms: (1) the stimulation of $5-\mathrm{HT}_{2 \mathrm{~A} / 2 \mathrm{C}}$ receptors and (2) through an interaction with the 5-HT uptake carrier (SERT).

\section{METHODS}

\section{Animal Care and Handling}

Female Sprague-Dawley rats (weighing between 150200 g; Taconic Farms, Germantown, NY) were used for all experiments. All animals were maintained on a 12-h light/dark cycle and had free access to food and water. All animal protocols were reviewed and approved by the New York University animal welfare committee.

\section{In Vivo Drug Treatments for the Translocation of PKC Binding Sites: Time Course Studies}

Animals received subcutaneous (SC) or intraperitoneal (IP) injections; either alone or in combination, of (+)-MDMA$\mathrm{HCl}$ (3,4-methylenedioxymethamphetamine; NIDA, Bethesda, MD), (( \pm$)$-2,5-dimethoxy-4-bromoamphetamine hydrobromide (DOB; RBI, Natick, MA), fluoxetine- $\mathrm{HCl}$ (a gift from Eli Lilly, Co.), ketanserin (Sigma; St. Louis, MO), $( \pm)$-cocaine- $\mathrm{HCl}$ (National Institute on Drug Abuse 
(NIDA); Bethesda, MD), or p-chloroamphetamine (pCA; Sigma, St. Louis, MO). The treatment regimens were comprised of one or two injections per day. Thirty minutes to 7 days after the last injection, the animals were decapitated and their brains rapidly removed followed by careful dissection of the cerebral cortex, hippocampus, and brainstem.

\section{${ }^{3} \mathrm{H}$-phorbol 12, 13 Dibutyrate $\left({ }^{3} \mathrm{H}-\mathrm{PDBu}\right)$ Binding to Treated and Untreated Tissue as a Measure of Membrane Bound PKC Binding Sites}

Fresh or frozen tissue samples were thawed and homogenized in an ice-cold buffer that limited active proteolysis. This buffer contained (mmol/L): Tris-HCl 20; ethylenediaminetetraammonium (EDTA) 2.0; phenylmethylsulfonyl fluoride (PMSF) 0.2; and ethyleneglycoltetraacetate (EGTA) 0.5 at pH 7.4. Tissue was homogenized in $10 \times \mathrm{v} / \mathrm{w}$ weight using a glass/teflon homogenizer or a Tissue Tearer Polytron (Brinkman). Samples were centrifuged in a Sorvall RC-5C centrifuge (using an SS-34 fixed-angle rotor) at 2,400 $g$ for $10 \mathrm{~min}$ to remove blood and other microsomal fractions. After discarding the pellet (P1), the supernatant was centrifuged for $15 \mathrm{~min}$ at $48,000 \mathrm{~g}$ to separate plasma membranes from the cytosolic fraction. The resulting pellet was resuspended in $40 \times$ original $\mathrm{v} / \mathrm{w}$ weight in resuspension buffer containing (mmol/L): Tris-HCl (38.5); Tris-Base (11.5); $\mathrm{NaCl}$ (100); and $\mathrm{CaCl}_{2}$ (1.0) at $\mathrm{pH}$ 7.4.

For radioligand binding, $40 \mu \mathrm{l}(0.1 \mathrm{mg}$ of protein as assessed by the method of Lowry et al. 1951) of membranes were plated onto 96-well plates (Nunc, Denmark) and allowed to equilibrate with $20 \mu \mathrm{l}$ of either assay buffer or $3 \mu \mathrm{mol} / \mathrm{L}$ phorbol 12-myristate 13-acetate (PMA; Sigma) to determine nonspecific binding. Scatchard analyses were performed to determine total binding and the initial ${ }^{3} \mathrm{H}-\mathrm{PDBu}$ binding parameters $\left(\mathrm{K}_{\mathrm{D}}\right.$ and $\left.\mathrm{B}_{\max }\right)$ using ${ }^{3} \mathrm{H}-\mathrm{PDBu}(1-40 \mathrm{nmol} / \mathrm{L})$ (New England Nuclear, specific activity $18.6 \mathrm{Ci} / \mathrm{mmol}$ ) in a total well volume of $200 \mu \mathrm{l}$ for $45 \mathrm{~min}$ at room temperature. Onepoint determinations were used to assay the number of translocated PKC binding sites $\left(7 \mathrm{nmol} / \mathrm{L}{ }^{3} \mathrm{H}-\mathrm{PDBu}\right)$ in some experiments. The tissue was harvested onto Titertek filtermats (coated with $0.1 \%$ polyethylimine (PEI) to reduce nonspecific binding) using a Titertek cell harvester, and the filters were placed in scintillation vials containing $3.0 \mathrm{ml}$ of Liquiscint (National Diagnostics). Samples were counted for $5 \mathrm{~min}$ in a Beckman liquid scintillation counter at an efficiency $40 \%$.

\section{Specific ${ }^{3} \mathrm{H}$-paroxetine Binding to Cortical Membranes}

Tissue was thawed to $4^{\circ} \mathrm{C}$ and homogenized at $40 \times \mathrm{v} /$ $\mathrm{w}$ in Tris- $\mathrm{HCl}$ buffer containing $(\mathrm{mmol} / \mathrm{L})$ : Tris- $\mathrm{HCl}$ (38.5); Tris-Base (11.5); $\mathrm{NaCl}$ (120); and $\mathrm{KCl}$ (5.6) at $\mathrm{pH}$
7.4 using a Brinkman polytron. The tissue was centrifuged at $30,000 \mathrm{~g}$ for $25 \mathrm{~min}$, and the resultant pellet was resuspended in $80 \times \mathrm{v} / \mathrm{w}$ in normal Tris $\mathrm{HCl}$. Then $160 \mu \mathrm{l}$ of membrane homogenate $(0.090-0.120 \mathrm{mg}$ of protein) was incubated in the presence of either $40 \mu \mathrm{l}$ of Tris- $\mathrm{HCl}$ buffer (total binding) or $1 \mu \mathrm{mol} / \mathrm{L}$ fluoxetine (Lilly, Indianapolis, IN; nonspecific binding) for $5 \mathrm{~min}$, and $200 \mu \mathrm{l}$ of ${ }^{3} \mathrm{H}$-paroxetine (final concentration 0.25 $\mathrm{nmol} / \mathrm{L}$; specific activity $15.3 \mathrm{Ci} / \mathrm{mmol} \mathrm{New}$ England Nuclear) was added and allowed to equilibrate in the dark for $120 \mathrm{~min}$ at $22^{\circ} \mathrm{C}$. Membrane filtration and radioactivity measurement proceeded as indicated above.

\section{Data Analysis and Statistics}

${ }^{3} \mathrm{H}-\mathrm{PDBu}$ and ${ }^{3} \mathrm{H}$-paroxetine binding curves were analyzed using an iterative curve fitting program. One-way and two-way analyses of variance (ANOVA) and the post hoc Tukey test were used for multiple comparisons at a minimum significance level of $p \leq .05$. Student's $t$-test was used when applicable for simple twosample tests. All statistical data was expressed as mean \pm $\mathrm{SD}$ of the indicated number of observations.

\section{RESULTS}

\section{Initial Parameters of ${ }^{3} \mathrm{H}-\mathrm{PDBu}$ Binding}

In the cortex, binding analyses demonstrated that ${ }^{3} \mathrm{H}-\mathrm{PDBu}$ binds with $\mathrm{a} \mathrm{K}_{\mathrm{D}}$ of $9.54 \pm 0.75 \mathrm{nmol} / \mathrm{L}$ and a $\mathrm{B}_{\max }$ of $11.72 \pm 1.84 \mathrm{pmol} / \mathrm{mg}$ protein (Figure 1 ). In the hippocampus, the $K_{D}$ was similar to that calculated in the cortex (hippocampus: $K_{D}=10.3 \pm 0.65$ ) (Figure 1). However, the $B_{\max }$ was significantly higher in the hippocampus than in the cerebral cortex (HIP: $18.8 \pm 1.20$ $\mathrm{pmol} / \mathrm{mg}$ protein vs. CTX: $11.72 \pm 1.84 \mathrm{pmol} / \mathrm{mg}$ protein, $p \leq .001)$.

\section{In Vivo Translocation of ${ }^{3} \mathrm{H}-\mathrm{PDBu}$ Binding Sites by MDMA: Dose and Time-Response Curve of MDMA-Mediated PKC Translocation}

Rats were injected with either saline or a single dose of MDMA in the range of $2.5-40 \mathrm{mg} / \mathrm{kg}$. One-point determinations $\left(7 \mathrm{nM} ;{ }^{3} \mathrm{H}-\mathrm{PDBu}\right)$ were used to assay the redistribution of PKC binding sites to the plasma membrane of cortical and hippocampal samples. At $3 \mathrm{~h}$ postinjection, MDMA produced a concentration-dependent increase in membrane-bound (particulate) PKC in the cortex beginning with the $10 \mathrm{mg} / \mathrm{kg}$ dose and continuing through the $40 \mathrm{mg} / \mathrm{kg}$ treatment (Figure 2). MDMA at 10 and $20 \mathrm{mg} / \mathrm{kg}$ increased the number of ${ }^{3} \mathrm{H}-\mathrm{PDBu}$ binding sites by $42.7 \%$ (15.96 $\pm 0.49 \mathrm{pmol} / \mathrm{mg}$ protein $)$ 
and $52.8 \%$ (17.1 pmol $/ \mathrm{mg}$ protein) over saline controls $(11.18 \pm 0.91 \mathrm{pmol} / \mathrm{mg}$ protein; $p \leq .001)$, respectively. Nonlinear curve-fitting analysis showed that MDMA produced a half-maximal translocation of ${ }^{3} \mathrm{H}-\mathrm{PDBu}$ binding sites at $22.5 \mathrm{mg} / \mathrm{kg}$. This stimulatory effect plateaus at doses $\geq 30 \mathrm{mg} / \mathrm{kg}$ ( $90.3 \%$ increase over control). In the hippocampus, MDMA elicited similar results by increasing membrane PKC density only with doses greater than $10 \mathrm{mg} / \mathrm{kg}$ (data not shown). In contrast to the changes in ${ }^{3} \mathrm{H}-\mathrm{PDBu}$ binding density, no alterations in ligand binding affinity occurred in the hippocampus or cortex after any dose of MDMA. During these dose-response experiments, two of the eight animals that received the highest dose $(40 \mathrm{mg} / \mathrm{kg})$ of MDMA died from the treatment.
We then investigated the time-course ( $30 \mathrm{~min}-24 \mathrm{~h}$ ) of MDMA-induced PKC activation after a single drug exposure $(20 \mathrm{mg} / \mathrm{kg})$. MDMA significantly increased the number of cortical PKC sites beginning at $3 \mathrm{~h}$ after injection, and this translocation remained significantly above control for $24 \mathrm{~h}$ (Figure 3). MDMA increased the number of plasma membrane PKC sites by: $67.9 \%(3 \mathrm{~h})$, $60.9 \%(6 \mathrm{~h}), 66.6 \%$ (12 h), and 60.4\% (24 h) (Figure 3). Scatchard analysis showed there was no difference in ligand binding affinity in any of the observed groups where a significant translocation was reported (data not shown). By $48 \mathrm{~h}$ after injection, the amount of particulate PKC was not significantly different than that observed in saline treated animals, nor were there any changes in ligand affinity.

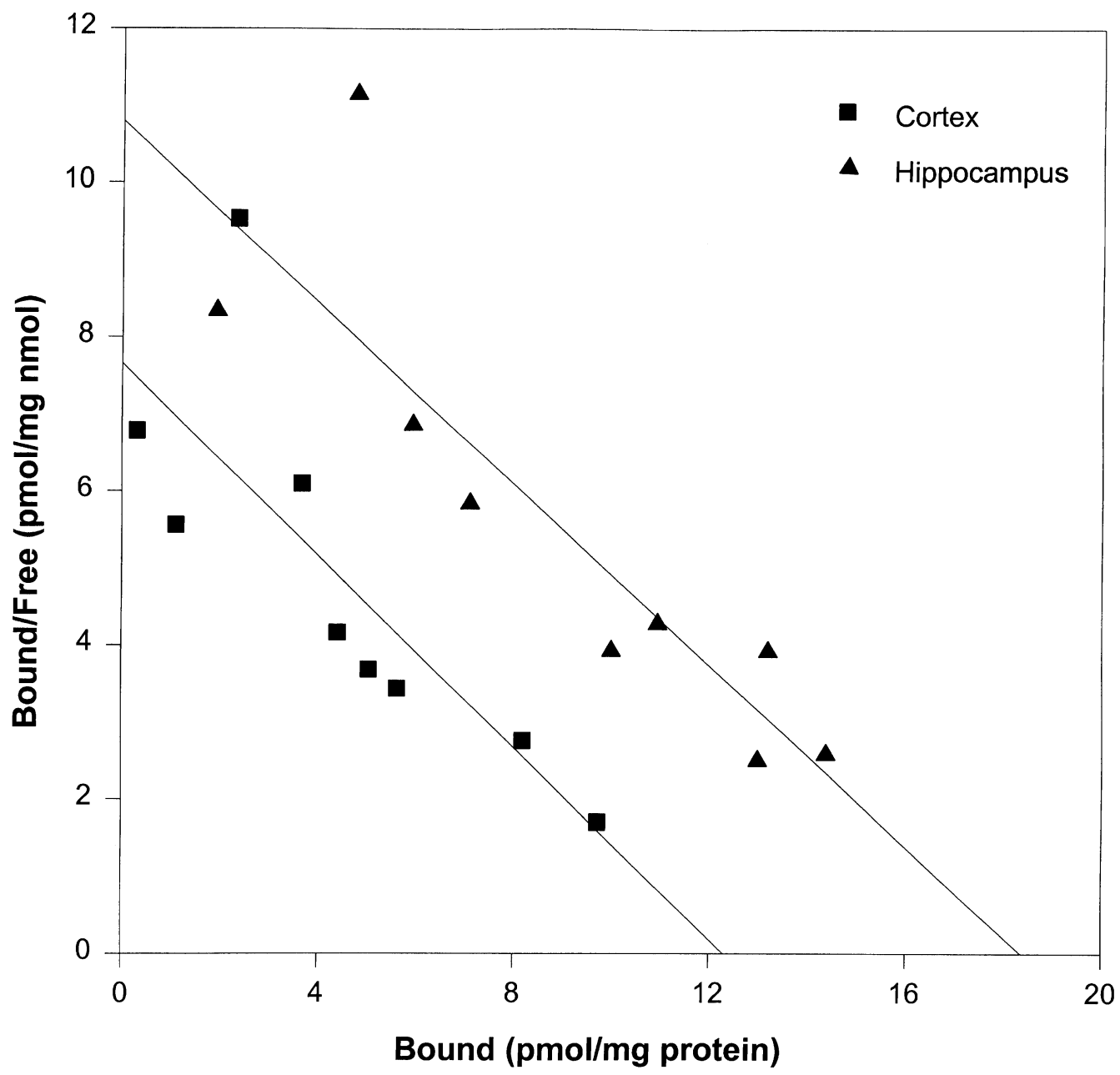

Figure 1. Scatchard isotherm transformation of ${ }^{3} \mathrm{H}-\mathrm{PDBu}$ binding to untreated rat cortical and hippocampal membrane homogenates. ${ }^{3} \mathrm{H}-\mathrm{PDBu}(1-40 \mathrm{nmol} / \mathrm{L})$ was incubated either in the presence of Locke's buffer (total binding) or $3 \mu \mathrm{mol} / \mathrm{L}$ PMA (nonspecific) for $45 \mathrm{~min}$ at room temperature. The data points represent specific binding of ${ }^{3} \mathrm{H}-\mathrm{PDBu}$ to untreated rat brain cortical (squares) or hippocampal membranes (triangles). Each data point is the average \pm SD of four determinations performed over three experiments $(n=3)$. The data was best-fit by a one-site model (Hill coefficient: 0.998). Results are represented as the $\mathrm{K}_{\mathrm{D}}(9.54=0.75 \mathrm{nmol} / \mathrm{L})$ and $\mathrm{B}_{\max }\left(11.72 \pm 1.84 \mathrm{pmol}\right.$ of ${ }^{3} \mathrm{H}-\mathrm{PDBu}$ bound $/ \mathrm{mg}$ protein in cortex $)$ and $\mathrm{K}_{\mathrm{D}}(10.30$ $\pm 0.65 \mathrm{nmol} / \mathrm{L})$ and $\mathrm{B}_{\max }\left(18.80 \pm 1.20 \mathrm{pmol}\right.$ of ${ }^{3} \mathrm{H}-\mathrm{PDBu}$ bound/mg protein in hippocampus $)$ of radioligand binding. All SD's were less than $8.0 \%$ of the calculated mean for all data points. 


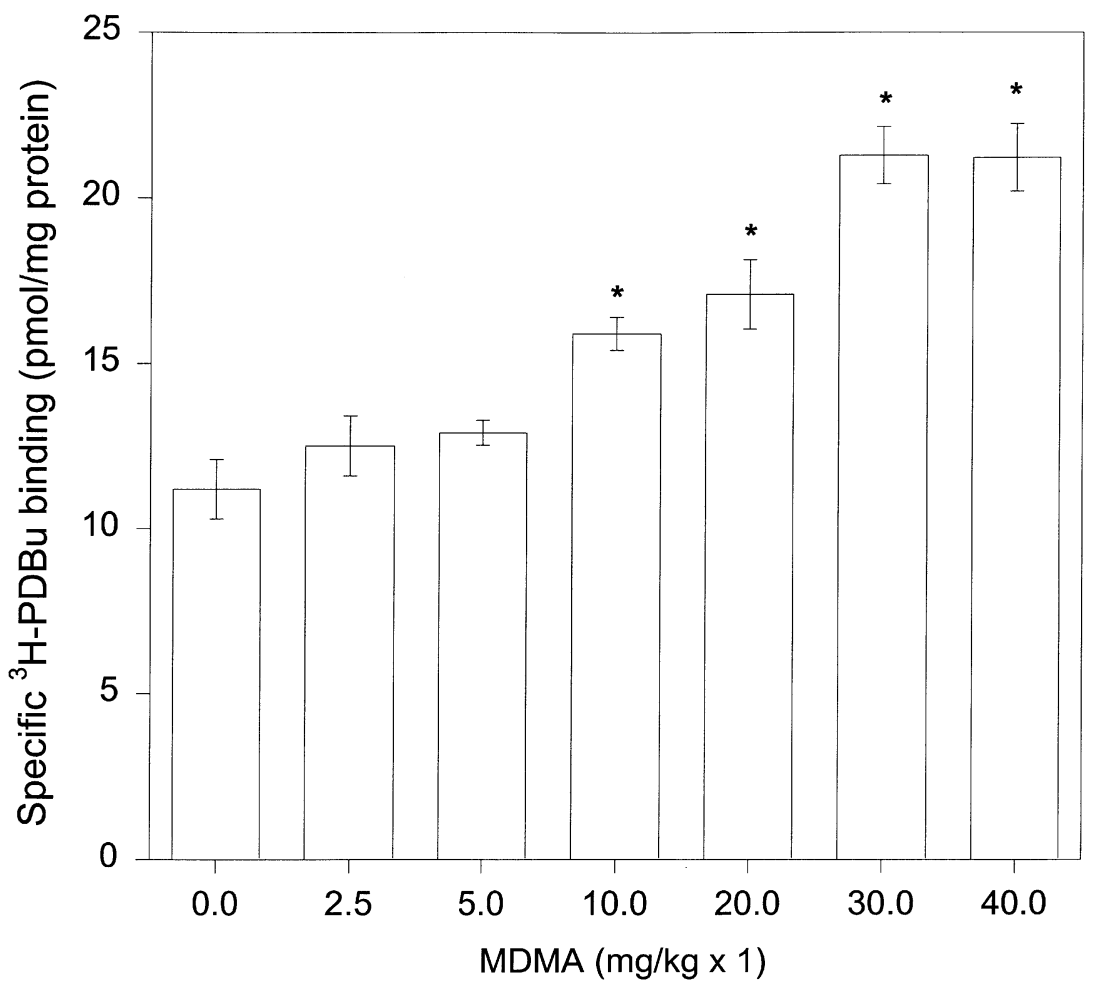

Figure 2. Rats received either saline or (+)-MDMA and were assayed for the redistribution of cortical ${ }^{3} \mathrm{H}-\mathrm{PDBu}$ binding sites $3 \mathrm{~h}$ later. ${ }^{3} \mathrm{H}-\mathrm{PDBu}$ binding to cortical membranes was performed as explained in the methods section. Asterisks indicate that the observed values were significantly different from the saline treated group at the $p \leq .001$ level using a one-way ANOVA $\left(F_{(6,21)}=132.23\right.$ with $\left.F_{\text {crit }}=2.57\right)$. The data points represent specific binding of ${ }^{3} \mathrm{H}-\mathrm{PDBu}$ to rat brain cortical membranes. Each data point is the average \pm SD of four determinations performed over three experiments $(n=3)$.

\section{Comparison of MDMA to Other Neuroactive Compounds for PKC Translocation}

Rats received a single dose of either pCA $(10 \mathrm{mg} / \mathrm{kg})$, DOB (5 mg/ kg), cocaine (COC- $10 \mathrm{mg} / \mathrm{kg}$ ), or fluoxetine (FLX- $20 \mathrm{mg} / \mathrm{kg}$ ) and were assayed for cortical $\mathrm{PKC}$ translocation at intervals ranging from $30 \mathrm{~min}$ to
24 h. PCA elicited a significant translocation of PKC beginning at $60 \mathrm{~min}$ after injection (saline $=9.98 \pm 0.56$ $\mathrm{pmol} / \mathrm{mg}$ protein vs. $14.04 \pm 0.02 \mathrm{pmol} / \mathrm{mg}$ protein; $(40.6 \%) p \leq .05)$ (Table 1). Maximal translocation occurred $6 \mathrm{~h}$ after treatment $(64.0 \%$ : saline $=10.45 \pm 0.42$ $\mathrm{pmol} / \mathrm{mg}$ protein vs. $17.14 \pm 0.20 \mathrm{pmol} / \mathrm{mg}$ protein;

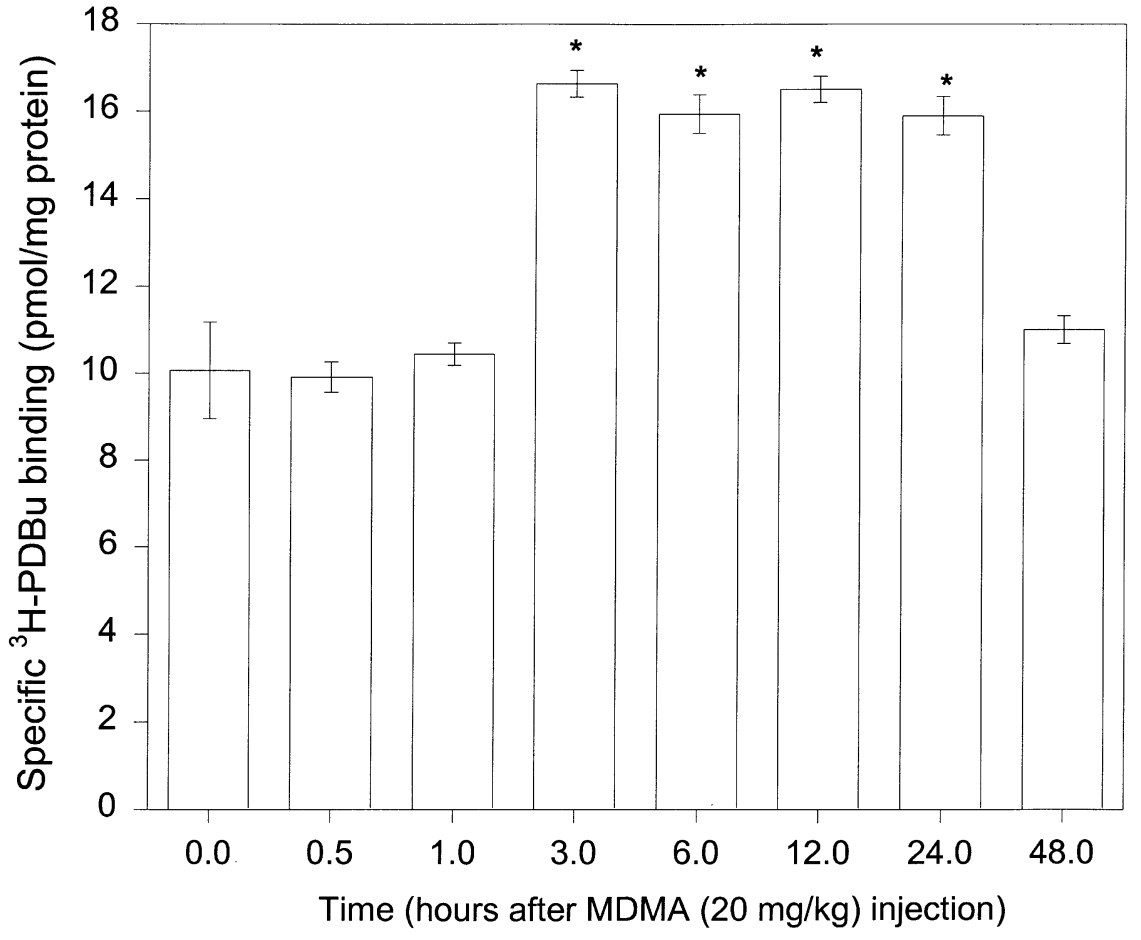

Figure 3. Rats received either saline or $(+)$-MDMA $(1 \times 20 \mathrm{mg} / \mathrm{kg})$ and were assayed for the redistribution of cortical ${ }^{3} \mathrm{H}-\mathrm{PDBu}$ binding sites at the time points indicated above. ${ }^{3} \mathrm{H}-\mathrm{PDBu}$ binding to cortical membranes was performed as explained in the methods section. Asterisks indicate that the observed values were significantly different from the saline treated group at the $p \leq .01$ level using one-way ANOVA $\left(\mathrm{F}_{(7,24)}=136.78\right.$ with $\mathrm{F}_{\text {crit }}=$ 2.42). The data points represent specific binding of ${ }^{3} \mathrm{H}-\mathrm{PDBu}$ to rat brain cortical membranes. Each data point is the average $\pm \mathrm{SD}$ of four determinations performed over three experiments $(n=3)$. 
$p \leq .05)$ and remained significantly above control for 12 $h$. The density of membrane-bound PKC binding sites returned to control levels by $24 \mathrm{~h}$ post-treatment. Neither cocaine, fluoxetine, nor DOB produced a significant increase in membrane-bound PKC binding sites across any of the time points investigated (Table 1).

\section{Effect of Fluoxetine $(20 \mathrm{mg} / \mathrm{kg}$ ) Pretreatment on MDMA-Mediated PKC Translocation}

Rats were pretreated with fluoxetine $(20 \mathrm{mg} / \mathrm{kg}) 1 \mathrm{~h}$ before receiving MDMA $(20 \mathrm{mg} / \mathrm{kg})$ or saline. Animals were killed $3 \mathrm{~h}$ after MDMA and assayed for ${ }^{3} \mathrm{H}-\mathrm{PDBu}$ binding in the cortex and hippocampus. Neither saline nor fluoxetine injections had any significant effect on the number of membrane-bound ${ }^{3} \mathrm{H}-\mathrm{PDBu}$ binding sites in the areas tested. As demonstrated before, MDMA elicited a $61.5 \%$ increase in PKC binding sites $(20.35 \pm 1.24 \mathrm{pmol} /$ $\mathrm{mg}$ protein) in the cortex compared to saline-treated animals (12.60 $\pm 1.02 \mathrm{pmol} / \mathrm{mg}$ protein) (Figure 4). In the hippocampus, MDMA was equally potent in mediating PKC translocation to plasma membranes (saline: $19.50 \pm$ 1.56 versus MDMA: $31.33 \pm 1.66 \mathrm{pmol} / \mathrm{mg}$ protein, $+60.6 \%$ over control; $p \leq .001$ ) (Figure 4 ). Fluoxetine pretreatment totally abolished the MDMA-mediated increase in PKC translocation in both areas without having an effect on kinase translocation by itself (Figure 4).

\section{Effect of Ketanserin $(10 \mathrm{mg} / \mathrm{kg}$ ) Pretreatment on MDMA-Mediated PKC Translocation}

Rats were pretreated with KET $(10 \mathrm{mg} / \mathrm{kg}) 1 \mathrm{~h}$ prior to receiving a single injection of pCA $(10 \mathrm{mg} / \mathrm{kg})$ or MDMA $(20 \mathrm{mg} / \mathrm{kg})$. Three $\mathrm{h}$ or 14 days later the animals were decapitated and their corticies assayed for PKC distribution and the number of 5-HT nerve terminals. Both MDMA and pCA increased the amount of membranebound ${ }^{3} \mathrm{H}-\mathrm{PDBu}$ binding sites by 59.3 and $60.6 \%$, respectively, $3 \mathrm{~h}$ after administration (Figure 5). Ketanserin had no effect on PKC translocation by itself (saline: $10.35 \pm$ 1.03 versus KET: $8.57 \pm 0.66 \mathrm{pmol} / \mathrm{mg}$ protein). However, ketanserin pretreatment $(60 \mathrm{~min})$ significantly reduced ( $p \leq .05$ by ANOVA) PKC translocation when given prior to each of the substituted amphetamines $(-18.7 \%$ decrease from maximum for MDMA alone and $-21.5 \%$ from pCA alone). Interestingly, membrane-bound $\mathrm{PKC}$ levels for both the KET/MDMA and KET/pCA groups remained significantly above control values despite the presence of the antagonist (KET/MDMA: $13.51 \pm 0.72$ and KET/pCA: $13.05 \pm 0.75 \mathrm{pmol} / \mathrm{mg}$ protein; $p \leq .05)$.

Finally, a subset of these animals were allowed to survive for 2 weeks before being assayed for cortical 5 -HT innervation by ${ }^{3} \mathrm{H}$-paroxetine $\left({ }^{3} \mathrm{H}-\mathrm{PAR}\right)$ binding. PCA decreased the number of ${ }^{3} \mathrm{H}-\mathrm{PAR}$ sites in the cortex by $69.0 \%$, whereas MDMA reduced this parameter by $42.2 \%$ compared to saline controls $(p \leq .001 ; \mathrm{F}(5,42)=$ 10.47) (Figure 6). Ketanserin had no effect on 5-HT terminal sites alone, but protected cortical 5-HT uptake sites from degeneration by MDMA and pCA (Figure 6). The number of cortical ${ }^{3} \mathrm{H}-\mathrm{PAR}$ sites in the KET/ MDMA and $\mathrm{KET} / \mathrm{pCA}$ groups were not significantly different from saline-treated animals.

\section{DISCUSSION}

Our previous report concluded that two injections of MDMA $(20 \mathrm{mg} / \mathrm{kg})$ were sufficient to increase the den-

Table 1. Translocation of Cortical PKC Binding Sites after a Single Administration of Neuroactive Compounds

\begin{tabular}{|c|c|c|c|c|c|c|c|c|}
\hline & & $0.5 \mathrm{~h}$ & $1 \mathrm{~h}$ & $3 \mathrm{~h}$ & $6 \mathrm{~h}$ & $12 \mathrm{~h}$ & $24 \mathrm{~h}$ & $48 \mathrm{~h}$ \\
\hline Saline & KD & $6.55 \pm 0.57$ & $6.22 \pm 0.59$ & $5.86 \pm 0.58$ & $6.57 \pm 0.68$ & $6.45 \pm 0.31$ & $6.36 \pm 0.47$ & $6.31 \pm 0.66$ \\
\hline $1 \mathrm{mg} / \mathrm{ml}$ & Bmax & $11.1 \pm 0.52$ & $9.98 \pm 0.56$ & $10.97 \pm 0.62$ & $10.45 \pm 0.42$ & $10.31 \pm 0.44$ & $10.09 \pm 0.44$ & $10.91 \pm 0.62$ \\
\hline Cocaine & $\mathrm{KD}$ & $6.46 \pm 0.59$ & $6.43 \pm 0.37$ & $6.47 \pm 0.66$ & $7.70 \pm 0.45$ & $7.44 \pm 0.75$ & $6.45 \pm 0.47$ & $6.82 \pm 0.43$ \\
\hline $10 \mathrm{mg} / \mathrm{kg}$ & Bmax & $9.97 \pm 0.27$ & $9.47 \pm 0.52$ & $10.08 \pm 0.21$ & $10.17 \pm 0.29$ & $9.91 \pm 0.48$ & $9.88 \pm 0.43$ & $9.99 \pm 0.24$ \\
\hline Floux. & KD & $6.43 \pm 0.41$ & $6.04 \pm 0.40$ & $6.23 \pm 0.18$ & $6.19 \pm 0.44$ & $5.71 \pm 0.24$ & $5.80 \pm 0.38$ & $5.89 \pm 0.32$ \\
\hline $20 \mathrm{mg} / \mathrm{kg}$ & Bmax & $10.42 \pm 0.39$ & $11.26 \pm 0.30$ & $11.21 \pm 0.31$ & $10.51 \pm 0.28$ & $10.50 \pm 0.25$ & $10.82 \pm 0.43$ & $11.14 \pm 0.27$ \\
\hline DOB & KD & $6.72 \pm 0.65$ & $6.73 \pm 0.77$ & $7.32 \pm 0.72$ & $8.14 \pm 0.75$ & $7.26 \pm 0.52$ & $6.63 \pm 0.42$ & $7.47 \pm 0.33$ \\
\hline $5.0 \mathrm{mg} / \mathrm{kg}$ & Bmax & $11.41 \pm 0.42$ & $10.98 \pm 0.48$ & $10.59 \pm 0.32$ & $11.07 \pm 0.25$ & $10.77 \pm 0.33$ & $11.35 \pm 0.48$ & $11.60 \pm 0.53$ \\
\hline PCA & KD & $7.02 \pm 0.32$ & $7.74 \pm 0.44$ & $6.71 \pm 0.55$ & $6.79 \pm 0.28$ & $6.95 \pm 0.38$ & $6.63 \pm 0.50$ & $6.36 \pm 0.32$ \\
\hline $10 \mathrm{mg} / \mathrm{kg}$ & Bmax & $10.36 \pm 0.26$ & $14.04 \pm 0.02 *$ & $17.33 \pm 0.17^{*}$ & $17.14 \pm 0.20^{*}$ & $13.29 \pm 0.07^{*}$ & $11.23 \pm 0.44$ & $11.58 \pm 0.39$ \\
\hline MDMA & KD & $6.75 \pm 0.34$ & $6.55 \pm 0.26$ & $6.72 \pm 0.51$ & $6.63 \pm 0.42$ & $6.72 \pm 0.43$ & $7.43 \pm 0.69$ & $7.33 \pm 0.44$ \\
\hline $20 \mathrm{mg} / \mathrm{kg}$ & Bmax & $9.91 \pm 0.35$ & $10.44 \pm 0.26$ & $16.64 \pm 0.30^{*}$ & $15.95 \pm 0.44^{*}$ & $16.51 \pm 0.30^{*}$ & $15.90 \pm 0.44^{*}$ & $11.01 \pm 0.32$ \\
\hline
\end{tabular}

Time course measuring the density of specific ${ }^{3} \mathrm{H}-\mathrm{PDBu}$ binding sites to cortical membranes after a single administration of the indicated compounds. Rat brains were analyzed for PKC translocation 0.5 to 48 hours after drug exposures. ${ }^{3} \mathrm{H}-\mathrm{PDBu}$ binding to cortical membrane homogenates was done as indicated in the methods section. Results are average $\pm \mathrm{SD}$ from four animals per experimental group. Results are represented as the $\mathrm{K}_{\mathrm{D}}$ $(\mathrm{nmol} / \mathrm{L})$ and $\mathrm{B}_{\max }\left(\mathrm{pmol}\right.$ of ${ }^{3} \mathrm{H}-\mathrm{PDBu}$ bound $/ \mathrm{mg}$ protein) of radioligand binding. The table demonstrates the results of a single experiment which was repeated at least twice with similar results.

$\mathrm{K}_{\mathrm{D}}=\mathrm{nmol} / \mathrm{L} \pm \mathrm{SD}$ and $\mathrm{B}_{\max }=\mathrm{pmol} / \mathrm{mg}$ protein $\pm \mathrm{SD}$.

${ }^{*} p \leq .05$ compared to saline controls by a one-way ANOVA and a post hoc Tukey test. 


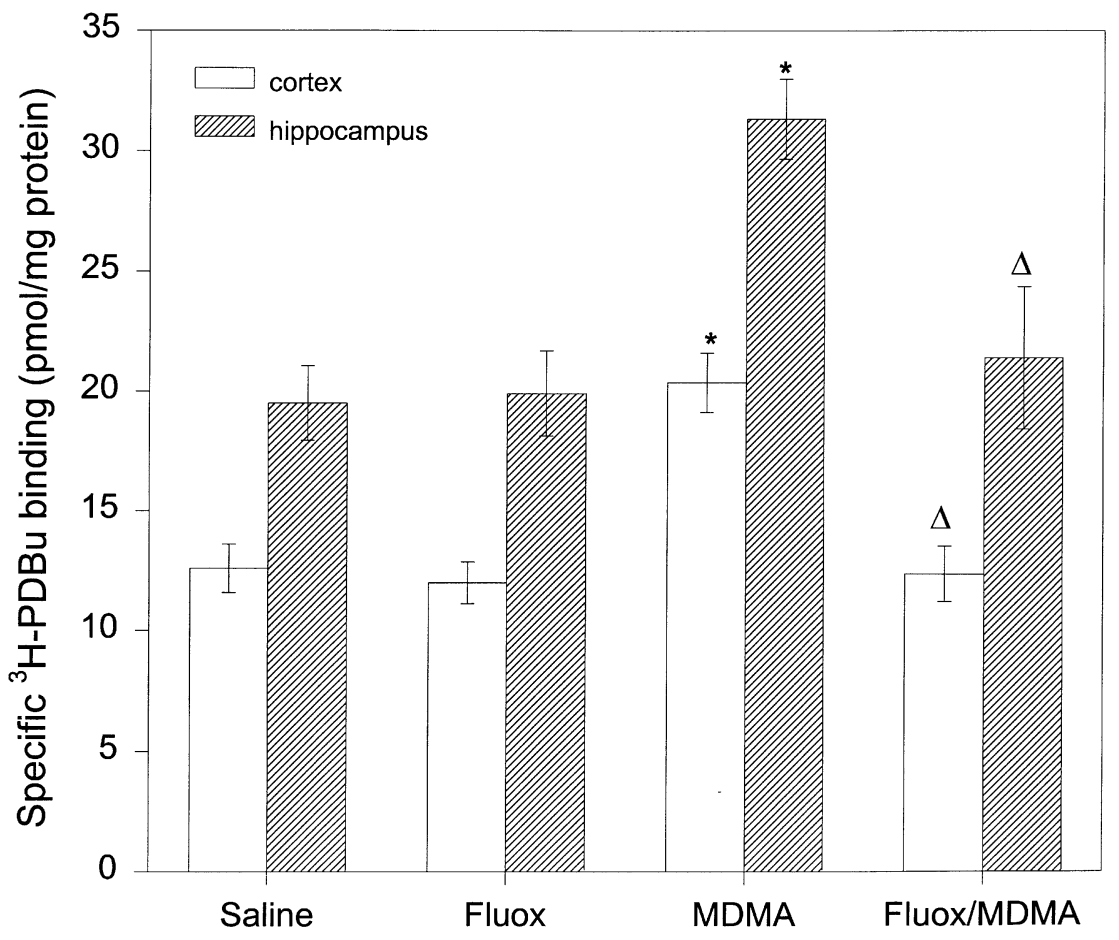

Figure 4. Rats were pretreated with either saline or fluoxetine $(20 \mathrm{mg} / \mathrm{kg}) 1 \mathrm{~h}$ prior to receiving saline or MDMA (20 $\mathrm{mg} / \mathrm{kg}$ ). Three hours after receiving the second injection, the animals were killed and their brains prepared for ${ }^{3} \mathrm{H}-\mathrm{PDBu}$ binding to cortical (plain bars) or hippocampal (hatched bars) membrane homogenates. ${ }^{3} \mathrm{H}-\mathrm{PDBu}$ binding was performed as indicated in the methods section. Each bar is the average \pm SD of four animals and each experiment was repeated at least three times $(n=3)$. The data bars represent specific binding of ${ }^{3} \mathrm{H}-\mathrm{PDBu}$ to rat brain membranes. ${ }^{*} p \leq .001$ compared to saline-treated groups by ANOVA $\left(\mathrm{F}_{(3,12)}=34.55\right)$ and the post hoc Tukey test. $\Delta \leq .001$ when compared to the MDMA alone treated group using similar statistical measures. sity of membrane-bound ${ }^{3} \mathrm{H}-\mathrm{PDBu}$ sites in rat cortical homogenates (Kramer et al. 1994, 1995). This increase within the particulate fraction was due to the translocation of cytosolic PKC to the plasma membrane. However, since MDMA has actions at both the 5-HT trans- porter and on postsynaptic 5-HT receptors, this study aimed to clarify which of these process(es) are involved in substituted amphetamine-induced PKC translocation.

The magnitude and duration of MDMA's long-term neurodegenerative effects are similarly dependent on

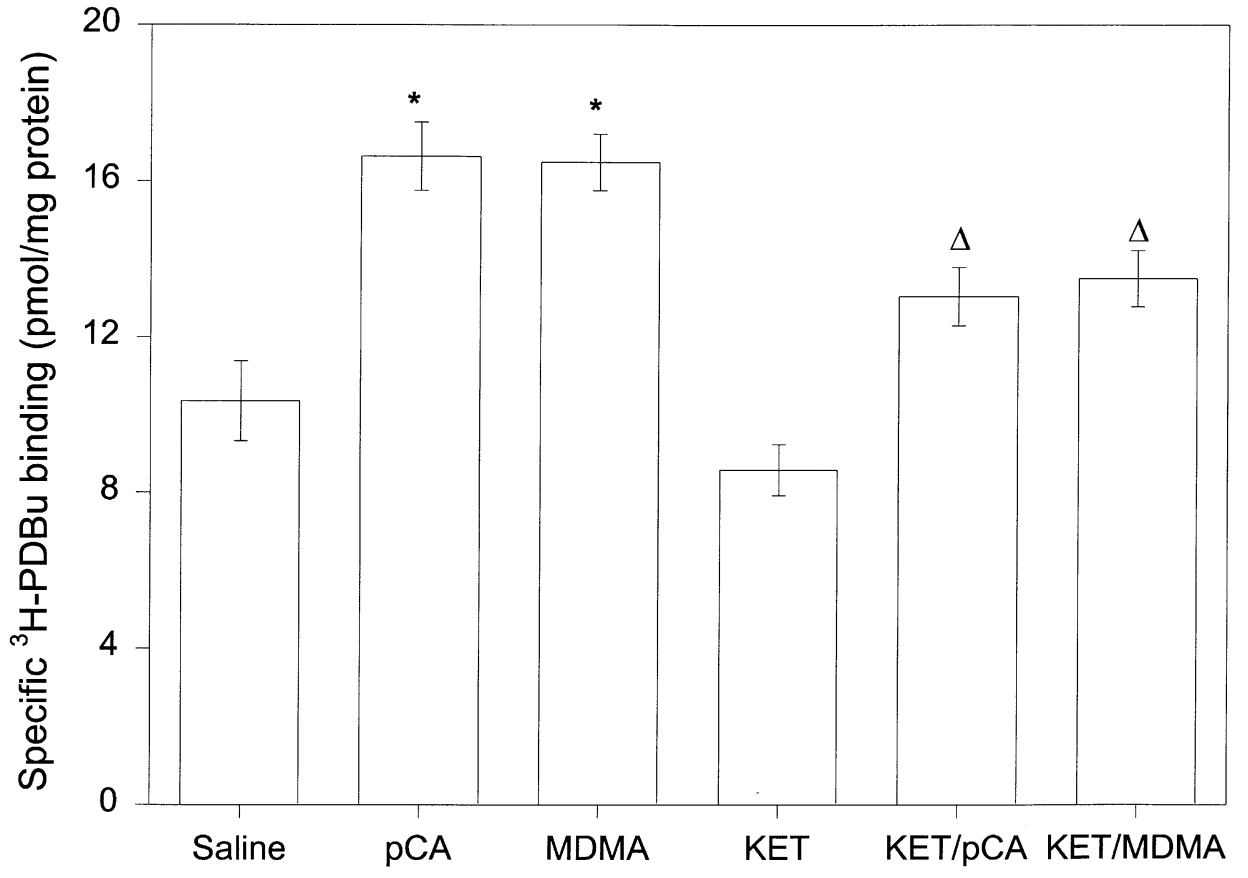

Figure 5. Rats were pretreated with either saline or ketanserin $(10 \mathrm{mg} / \mathrm{kg}) 1 \mathrm{~h}$ prior to receiving saline, pCA $(10 \mathrm{mg} / \mathrm{kg})$, or MDMA (20 mg/kg). Three hours after receiving the second injection, the animals were killed and their brains prepared for ${ }^{3} \mathrm{H}-\mathrm{PDBu}$ binding to cortical membrane homogenates. ${ }^{3} \mathrm{H}-\mathrm{PDBu}$ binding was performed as indicated in the methods section. Each bar is the average \pm SD of four animals and each experiment was repeated at least three times $(n=3)$. The data bars represent specific binding of ${ }^{3} \mathrm{H}$ $\mathrm{PDBu}$ to rat brain cortical membranes. ${ }^{*} p \leq .001$ compared to saline-treated groups by ANOVA $\left(\mathrm{F}_{(5,18)}=10.47\right)$ and the post hoc Tukey test. $\Delta \leq .05$ when compared to the MDMA or pCA alone treated groups using similar statistical measures. 
the dose given to rats and non-human primates (Ricaurte et al. 1988). MDMA administered at low concentrations (2.5-5.0 $\mathrm{mg} / \mathrm{kg}$ ) does not produce PKC translocation (Figure 2) nor does it produce neurotoxicity, suggesting that PKC translocation may be an intermediate step culminating in cell damage (Battaglia et al. 1987, 1988; Broening et al. 1994). These lower doses, however, do release 5-HT in vitro and in vivo and suggest that neurotransmitter release, alone, is not enough to promote long-term 5-HT deficits. For instance, administration of the R-(-) form of MDMA produces an acute, but not a long-term depletion in brain [5-HT] (Schmidt 1987). Lasting decreases in serotonergic biomarkers (5-HT, 5-HIAA, and ${ }^{3} \mathrm{H}$-paroxetine binding sites) are only observed with doses of MDMA greater than $10 \mathrm{mg} / \mathrm{kg}$ (Commins et al. 1987; Battaglia et al. 1988; Broening et al. 1994). Amphetamine (AMPH), which is a potent DA releaser, also produces PKC translocation and is correspondingly neurotoxic to DA-containing nerve terminals after high doses (Fisher and Cho 1979; Giambalvo 1992a,b).

MDMA-mediated PKC translocation was also found to be dependent on time. A single injection of MDMA $(20 \mathrm{mg} / \mathrm{kg})$ produced a significant increase in particulate PKC density lasting from $3 \mathrm{~h}$ to $24 \mathrm{~h}$ after MDMA administration. This time course is similar to MDMA's 5-HT release profile, in vivo (Schmidt 1987). MDMA's ability to increase synaptic 5-HT arises from a direct interaction with the high-affinity 5-HT transporter, which is found on both neurons and glial cells (Kimelberg 1986; Berger et al. 1992a,b; Rudnick and Wall 1992a,b). Single injections of MDMA (10-20 mg/ kg) acutely deplete cortical and striatal 5-HT levels between 3 and $6 \mathrm{~h}$ after administration (Schmidt 1987; Schmidt and Taylor 1987; Broening et al. 1994). These results support the hypothesis that increased extracellular 5-HT contributes to PKC activation in neural tissue (Conn and Sanders-Bush 1985, 1986; Kagaya et al. 1990). By 48 h after MDMA exposure, there was no measurable difference in cortical PKC binding sites between treatment groups. The loss of MDMA's kinase translocating effect may be due to the elimination of MDMA from the body, or the cessation of the 5-HT release response (Cho et al. 1990).

We then carried out similar experiments using a variety of 5-HT agonists. PCA $(10 \mathrm{mg} / \mathrm{kg})$ is a potent 5 -HT releaser/uptake inhibitor and degenerates 5-HT nerve terminals similarly, but more potently than MDMA (Fuller et al. 1975). DOB (5.0 mg/ $\mathrm{kg})$, a hallucinogen, is a selective $5-\mathrm{HT}_{2 \mathrm{~A} / 2 \mathrm{C}}$ receptor agonist that has been found to translocate PKC in brain slices (Kagaya et al. 1990). Finally, two 5-HT uptake inhibitors were chosen, fluoxetine (FLX: $20 \mathrm{mg} / \mathrm{kg}$ ) and cocaine (COC: $10 \mathrm{mg} / \mathrm{kg}$ ), because of their ability to increase synaptic 5-HT levels by inhibiting the 5-HT uptake transporter. PCA (10 $\mathrm{mg} / \mathrm{kg}$ ) elicited a significant translocation of PKC in the cortex beginning at $1 \mathrm{~h}$, and this response remained significantly above control through $12 \mathrm{~h}$ post-injection (Table 1). PCA produced its peak effects on PKC activation at $3 \mathrm{~h}(+57.96 \%$ over saline), whereas MDMA induced a steady translocation, which did not change in intensity, during the period in which it was mobilized (3-24 h). Twelve hours after pCA administration, the density of membrane PKC sites was already beginning to decline from its peak level (Table 1). The density of ${ }^{3} \mathrm{H}-\mathrm{PDBu}$ sites returned to control levels by $24 \mathrm{~h}$ after a single

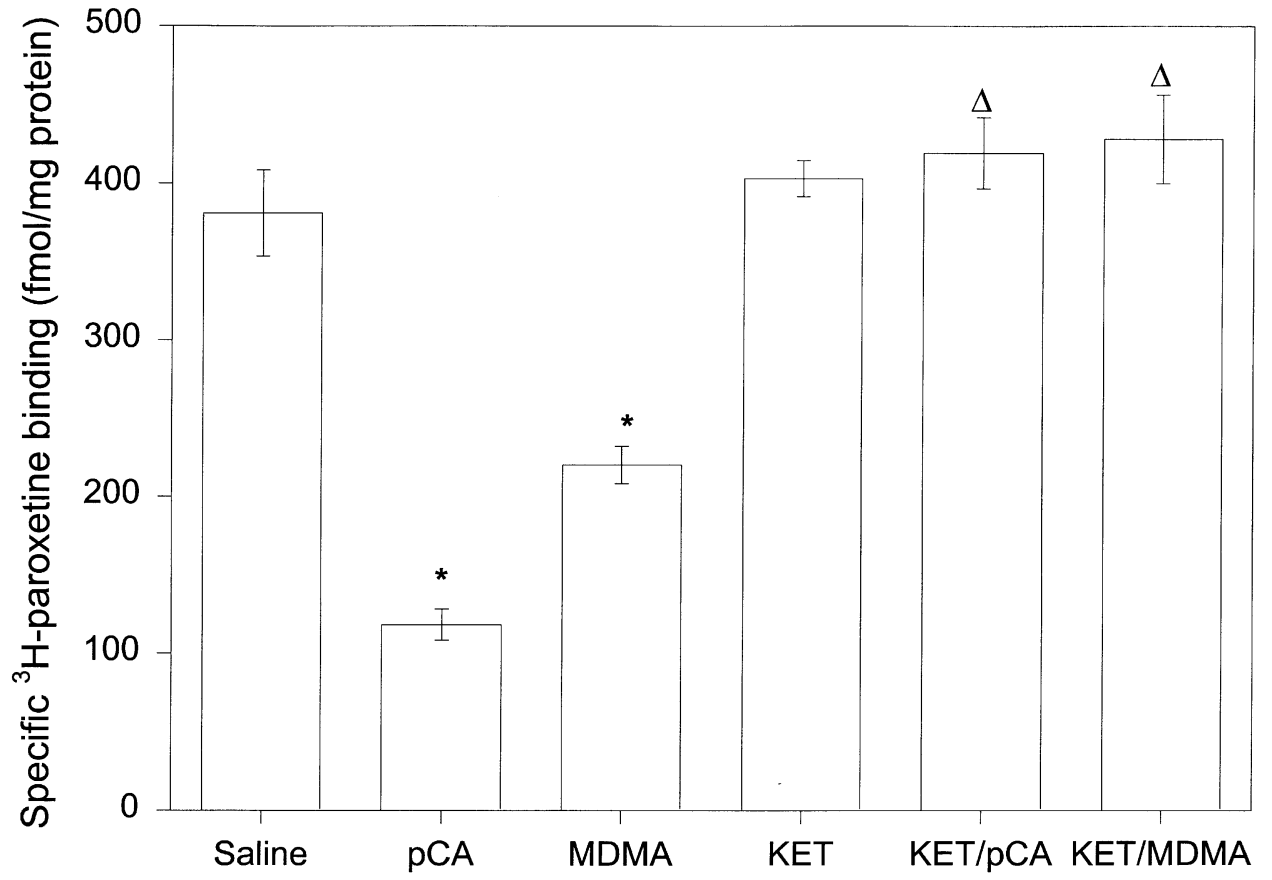

Figure 6. Rats were pretreated with either saline or ketanserin $(10 \mathrm{mg} / \mathrm{kg}) 1 \mathrm{~h}$ prior to receiving saline, $\mathrm{pCA}$ (10 mg/kg), or MDMA (20 mg/ $\mathrm{kg})$. Two weeks after receiving the second injection, the animals were killed and their brains prepared for ${ }^{3} \mathrm{H}$-paroxetine binding to cortical membrane homogenates. ${ }^{3} \mathrm{H}$-paroxetine binding was performed as indicated in the methods section. Each bar is the average \pm SD of four animals and each experiment was repeated at least three times $(n=3)$. The data bars represent specific binding of ${ }^{3} \mathrm{H}-\mathrm{PRX}$ to rat brain cortical membranes. ${ }^{*} p \leq .001$ compared to saline-treated groups by ANOVA $\left(\mathrm{F}_{(5,18)}=10.47\right)$ and the post hoc Tukey test. 
pCA exposure, whereas translocation produced by MDMA remained significantly above control at that time.

PCA is a potent 5-HT releaser, uptake inhibitor $\left(\mathrm{EC}_{50}: 3.43 \mu \mathrm{mol} / \mathrm{L}\right.$ and $\mathrm{IC}_{50}: 0.184 \mu \mathrm{mol} / \mathrm{L}$, respectively), and a powerful 5-HT neurotoxin, which causes selective ablation of fine 5-HT-IR axons after relatively low doses (0.5-2.5 mg/kg) (Harvey et al. 1975; Johnson et al. 1991; Berger et al. 1989, 1992a). In comparison, higher concentrations of MDMA are required for inhibiting 5-HT uptake and promoting its release $\left(\mathrm{IC}_{50}\right.$ : 0.425 $\mu \mathrm{mol} / \mathrm{L}$ and $\mathrm{EC}_{50}: 7.96 \mu \mathrm{mol} / \mathrm{L}$, respectively) compared to pCA (Johnson et al. 1991; Berger et al. 1992b). Consequently, the time discrepancies observed for PKC translocation, and the development of neurotoxicity by MDMA and $\mathrm{pCA}$, may reflect each compound's relative ability to increase synaptic 5-HT levels (Schmidt and Taylor 1987; Berger et al. 1992b; Kokotos Leonardi and Azmitia 1994). PCA produces lasting changes in the 5-HT innervation of the forebrain (loss of ${ }^{3} \mathrm{H}$-paroxetine binding sites) as early as $24 \mathrm{~h}$ after exposure, but similar changes after MDMA are not observed for at least 3 days (Nash et al. 1991; Steele et al. 1994). Consequently, the increased potency of pCA as a 5-HT releaser could explain why its temporal-response curve for PKC translocation lies to the left of MDMA's (Table 1 and Figure 3).

Several other agents were tested for their potential for PKC activation, in vivo. Other 5-HT activating drugs like cocaine $(10 \mathrm{mg} / \mathrm{kg})$ (DA, NE, and 5-HT uptake inhibitor), $\mathrm{DOB}(5 \mathrm{mg} / \mathrm{kg})$ (potent $5-\mathrm{HT}_{2 \mathrm{~A} / 2 \mathrm{C}}$ agonist), and fluoxetine $(20 \mathrm{mg} / \mathrm{kg}$ ) (selective 5 -HT uptake inhibitor) did not increase the density of membrane bound PKC sites, nor affect ligand affinity at any time point investigated (Table 1). The lack of effect of acute FLX, COC, and DOB on PKC translocation may underlie their low neurodegenerative potential. Fluoxetine $(10 \mathrm{mg} / \mathrm{kg})$ administered for 21 days was found to actually upregulate the density of ${ }^{3} \mathrm{H}$-paroxetine binding sites in the cortex and hippocampus (Hrdina and $\mathrm{Vu}$ 1993). These changes are dissimilar to those reported after MDMA and pCA exposure and suggest that uptake inhibition alone does not lead to neurotoxicity. For second messenger systems, fluoxetine has shown a potent inhibitory effect on at least one intracellular kinase $\left(\mathrm{Ca}^{2+} /\right.$ calmodulin-dependent protein kinase) in nonneural cells (Silver et al. 1986). Fluoxetine, while a selective 5-HT uptake inhibitor $\left(\mathrm{IC}_{50} 10.2 \mathrm{nmol} / \mathrm{L}\right.$ ) is not a potent 5-HT releaser unless it is given at very high concentrations ( $\mathrm{EC}_{50}\left({ }^{3} \mathrm{H}-5-\mathrm{HT}\right.$ release): $\left.23.0 \mu \mathrm{mol} / \mathrm{L}\right)(\mathrm{Hek}-$ matpanah and Peroutka 1990; Hyde and Bennett 1994). Cocaine is a highly selective DA and NE uptake inhibitor but is a relatively weak 5-HT releaser in a synaptosomal preparations $\left(\mathrm{EC}_{50} 10.0 \mu \mathrm{mol} / \mathrm{L}\right.$ ) (Miller et al. 1980; Hyde and Bennett 1994; Kramer and Azmitia 1994).

Similarly, acute treatment with $5.0 \mathrm{mg} / \mathrm{kg}$ DOB was unable to induce a long-term translocation of PKC to cortical membranes. This finding was unexpected when compared to DOB's ability to promote PKC translocation in vitro (Kagaya et al. 1990; Wang and Friedman 1990). Unfortunately, there is not much evidence of DOB's ability to induce these effects in vivo; therefore, data regarding this response in live animals remain uncertain. However, a single injection of another $5-\mathrm{HT}_{2 \mathrm{~A} / 2 \mathrm{C}}$ agonist, ( \pm )-2,5-dimethoxy-4-iodoamphetamine (DOI), produces a rapid desensitization of the $5-\mathrm{HT}_{2 \mathrm{~A} / 2 \mathrm{C}}$ receptor within minutes of a single low dose $(5 \mathrm{mg} / \mathrm{kg})$ (Pranzatelli 1991). Consequently, the absence of prolonged PKC translocation after a high-affinity agonist, like DOI and DOB, may reflect a consequence of receptor desensitization. This rapid functional loss may be neuroprotective by attenuating the aftermath of prolonged $5-\mathrm{HT}_{2 \mathrm{~A} / 2 \mathrm{C}}$ receptor activation. Therefore, compounds that are relatively weak 5-HT releasers (FLX and $\mathrm{COC}$ - - or rapidly desensitize $5-\mathrm{HT}_{2 \mathrm{~A} / 2 \mathrm{C}}$ receptors (DOB)-appear not to increase PKC translocation, and this ineffectiveness may explain their low neurotoxic potential.

An increase in extracellular 5-HT appears essential for PKC translocation and for the eventual ablation of fine 5HT axons by substituted amphetamines. Pretreatment of rats with fluoxetine not only prevents PKC translocation, but also the acute reduction in brain 5-HT levels and the long-term decrease in cortical 5-HT uptake sites after MDMA (this report and Schmidt 1987). Similarly, depletion of endogenous 5-HT stores prior to administration of neurotoxic doses of pCA or MDMA also blocks their PKC stimulating and neurotoxic effects (Berger et al. 1992a,b; Gu and Azmitia 1993; Kramer et al. 1995). Consequently, both neurotransmitter release and PKC translocation show a sensitivity to fluoxetine, presumably by interfering with the drug from binding to the 5-HT transporter (SERT) (Berger et al. 1992b; Azmitia et al. 1993). By inhibiting the 5-HT transporter, FLX blocks MDMA from its primary active site which prevents 5HT release and/or the entrance of MDMA into the 5-HT nerve terminal (Rudnick and Wall 1992a,b).

$5-\mathrm{HT}_{2 \mathrm{~A} / 2 \mathrm{C}}$ antagonists like ketanserin are also effective at reducing the neuropathology induced by MDMA (Nash et al. 1991). Accordingly, several laboratories have reported that the $5-\mathrm{HT}_{2 \mathrm{~A} / 2 \mathrm{C}}$ receptor controls many intermediate physiological changes associated with MDMA exposure. Hyperthermia, increases in DA synthesis and release, elevations in intracellular calcium, glycogenolysis in astrocytes, and the potentiation of substituted amphetamine-mediated glucocorticoid release have all been shown to be modulated by activation of this receptor subtype following MDMA (Nash and Brodkin 1991; Schmidt et al. 1991; Malberg et al. 1994; Yau et al. 1994; Novotney and Lowy 1995; Poblete and Azmitia 1995). Therefore, direct or indirect stimulation of the 5- $\mathrm{HT}_{2 \mathrm{~A} / 2 \mathrm{C}}$ receptor by MDMA (or 5-HT) produces varied metabolic and behavioral changes in exposed animals. 
In the present study, ketanserin pretreatment reduced PKC translocation after MDMA administration by $18.7 \%$ and by $21.5 \%$ after pCA, and each value was significantly different from the stimulant-alone groups $(p \leq .05)$ (Figure 5). Interestingly, ketanserin was more effective in attenuating the loss of cortical ${ }^{3} \mathrm{H}$-paroxetine $\left({ }^{3} \mathrm{H}-\mathrm{PAR}\right)$ binding sites after $\mathrm{pCA}$ and MDMA. MDMA and pCA reduced the density of ${ }^{3} \mathrm{H}-\mathrm{PAR}$ sites in the cortex to 42.2 and $69.0 \%$ of control, respectively (Figure 6). Ketanserin pretreatment totally abolished this loss of 5-HT uptake sites in the cerebral cortex (Figure 6). In contrast, ketanserin only partially blocked PKC translocation, suggesting that kinase activation does not only occur through postsynaptic $5-\mathrm{HT}_{2 \mathrm{~A} / 2 \mathrm{C}}$ receptor stimulation. However, in the presence of ketanserin, MDMA is still capable of binding to the SERT and stimulating 5-HT release. The partial reversal by ketanserin suggests that $5-\mathrm{HT}_{2 \mathrm{~A} / 2 \mathrm{C}}$ receptor activation is only one cellular mechanism by which MDMA stimulates PKC translocation and only one factor that contributes to 5-HT toxicity.

One of these other mechanisms may involve stimulation of the $5-\mathrm{HT}_{3}$ receptor. Specific $5-\mathrm{HT}_{3}$ agonists have been shown to increase phosphoinositide hydrolysis and $\mathrm{IP}_{3}$ formation in several tissue types (Edwards et al. 1993; Yang et al. 1994). Interestingly, 5- $\mathrm{HT}_{3}$-mediated phospholipase C (PLC) activation appears to be a calciumdependent process (Edwards et al. 1993). This calcium requirement can be readily supplied by the calcium mobilizing properties of MDMA (Park and Azmitia 1991). Additionally, the inhibitory actions of FLX on MDMAmediated PKC translocation support the possibility that MDMA may also promote PKC translocation within 5-HT nerve terminals. Therefore, besides the participation of $5-\mathrm{HT}_{2 \mathrm{~A} / 2 \mathrm{C}}$ receptors, PKC translocation after MDMA might occur via alternate mechanisms involving the $5-\mathrm{HT}_{3}$ receptor complex and the SERT.

The prolonged activation of PKC after MDMA may have important implications for the development of 5-HT nerve terminal toxicity. Previous studies have shown that sustained PKC translocation-in cerebellar granule cells, in vitro, and in the hippocampus, in vivo-leads to a destabilization of intracellular calcium homeostasis and cell death (Favaron et al. 1988; Onodera et al. 1989). Of the many cellular mechanisms that are believed to promote the loss of 5-HT nerve terminals after MDMA, an increase in extrasynaptic 5-HT and DA are among the most understood (Berger et al. 1989, 1992a,b; Nash 1990). Co-administration of a $5-\mathrm{HT}_{2 \mathrm{~A} / 2 \mathrm{C}}$ agonist, DOI, with MDMA potentates both DA release and 5-HT neurotoxicity (Gudelsky et al. 1994). Recently, both the DA and 5-HT uptake transporters have been shown to be substrates for PKC-mediated phosphorylation, and this modification significantly decreases monoamine re-uptake (Miller and Hoffman 1994; Huff et al. 1997). Therefore, PKC activation may potentiate the increase in extracellular DA and 5-HT and contribute to neurotoxicity, by preventing the clearance of monoamines from the synaptic cleft.

In summary, the PKC translocating effects of MDMA and pCA appear to be related to their ability to bind to the 5-HT transporter, release 5-HT from central serotonergic neurons, and to stimulate $5-\mathrm{HT}_{2 \mathrm{~A} / 2 \mathrm{C}}$ receptors. Additionally, PKC activation may be occurring within the 5-HT nerve terminal in response to MDMA binding to the SERT, coupled with increased calcium influx into the 5-HT terminal bouton. Increases in intracellular calcium can promote PKC translocation in the absence of receptor-stimulated phospholipid hydrolysis. (Melloni et al. 1985). A fluoxetine-sensitive increase in ${ }^{45} \mathrm{Ca}^{2+}$ uptake has been reported to occur in cortical synaptosomes incubated with MDMA concentrations known to release ${ }^{3} \mathrm{H}-5-\mathrm{HT}$ (Azmitia et al. 1993). Fluoxetine was able to totally inhibit MDMA's effect on PKC translocation, presumably by preventing 5-HT release and serotonin receptor stimulation. Our results demonstrate that MDMA increases the density of membrane-bound phorbol ester binding sites when administered acutely in vivo, and that this effect is differentially sensitive to SERT and 5- $\mathrm{HT}_{2 \mathrm{~A} / 2 \mathrm{C}}$ antagonists. We are currently performing similar experiments in vitro, using synaptosomes in different ionic conditions, to fully elucidate the mechanism of this interesting response to substituted amphetamines.

\section{REFERENCES}

Appel NM, Contrera J, DeSouza EB (1989): Fenfluramine selectively and differentially decreases the density of serotonergic nerve terminals in rat brain: Evidence from immunocytochemical studies. J Pharmacol Exp Ther 249:928-943

Azmitia EC (1989): Nimodipine attenuates NMDA- and MDMA-induced toxicity of fetal serotonergic neurons: Evidence for a generic model of calcium toxicity. In Gispen WH, Traber J (eds), Nimodipine and Central Nervous System Functions: New Vistas. Stuttgart, Springer-Verlag, pp 141-159

Azmitia EC, Murphy RB, Whitaker-Azmitia PM (1990): MDMA (Ecstasy) effects on cultured serotonergic neurons: Evidence for $\mathrm{Ca} 2+$-dependent toxicity linked to release. Brain Res 510:97-103

Azmitia EC, Kramer HK, Kim-Park WK (1993): Nimodipine blocks the efflux of $45 \mathrm{Ca} 2+$ and enhances the depolarization-induced release of $3 \mathrm{H}-5-\mathrm{HT}$ from CNS synaptosomes. In Scriabine A, Janis RA, Triggle DJ (eds), Drugs in Development. Branford, Neva Press, pp 437-446

Battaglia G, Yeh SY, O'Hearn E, Molliver ME, Kuhar MJ, DeSouza EB (1987): 3,4-Methylenedioxymethamphetamine and 3,4-methylenedioxyamphetamine destroy serotonin terminals in the rat brain: Quantification of neurodegeneration by measurement of $[3 \mathrm{H}]$ paroxetinelabeled serotonin uptake sites. J Pharmacol Exp Ther 242:911-916 
Battaglia G, Brooks BP, Kulsakdinun C, DeSouza EB (1988): Pharmacological profile of MDMA (3,4-methylenedioxymethamphetamine) at various brain recognition sites. Eur J Pharmacol 149:159-163

Berger UV, Grzanna R, Molliver ME (1989): Depletion of serotonin using p-chlorophenylalanine (PCPA) and reserpine protects against the neurotoxic effects of $\mathrm{p}$-chloroamphetamine (PCA) in the brain. Exp Neurol 103: 111-115

Berger UV, Grzanna R, Molliver ME (1992a): The neurotoxic effects of p-chloroamphetamine in rat brain are blocked by prior depletion of serotonin. Brain Res 578:177-185

Berger UV, Gu XF, Azmitia EC (1992b): The substituted amphetamines 3,4-methylenedioxymethamphetamine, methamphetamine, p-chloroamphetamine and fenfluramine induce 5-hydroxytryptamine release via a common mechanism blocked by fluoxetine and cocaine. Eur J Pharmacol 215:153-160

Berridge MJ (1984): Inositol triphosphate and diacylglycerol as second messengers. Biochem J 220:345-360

Broening HW, Bacon L, Slikker Jr. W (1994): Age modulates the long-term but not the acute effects of the serotonergic neurotoxicant 3,4-methylenedioxymethamphetamine. J Pharmacol Exp Ther 271:285-293

Castanga M, Takai Y, Kaibuchi K, Sano K, Kikkawa U, Nishizuka Y (1982): Direct activation of calcium-activated, phospholipid-dependent protein kinase by tumor-promoting phorbol esters. J Biol Chem 257:7847-7851

Cho AK, Hiramatsu M, DiStefano EW, Chang AS, Jenden DJ (1990): Stereochemical differences in the metabolism of 3,4-methylenedioxymethamphetamine in vivo and in vitro: A pharmacokinetic analysis. Drug Metab Disp 18:686-691

Commins DL, Vosmer G, Virus RM, Wollverton WL, Schuster CR, Seiden LS (1987): Biochemical and histological evidence that methylenedioxymethamphetamine (MDMA) is toxic to the rat brain. J Pharmacol Exp Ther 241:338-345

Conn PJ, Sanders-Bush E (1985): Serotonin-stimulated phosphoinositide turnover: Mediation by the S2 binding site in rat cerebral cortex but not in subcortical regions. J Pharmacol Exp Ther 234:195-203

Conn PJ, Sanders-Bush E (1986): Regulation of serotoninstimulated phosphoinositide hydrolysis: Relation to the serotonin 5-HT2 binding site. J Neurosci 6:3669-3675

Edwards E, Ashby CR, Wang RY (1993): Further characterization of 5-HT and 5-HT3 receptor agonists-stimulated phosphoinositol phosphates accumulation. Brain Res 617:113-119

Farfel GM, Vosmer GL, Seiden LS (1992): The N-methyl-Daspartate antagonist MK-801 protects against serotonin depletions induced by methamphetamine, 3,4-methylenedioxymethamphetamine and p-chloroamphetamine. Brain Res 595:121-128

Favaron M, Manev H, Alho H, Bertolino M, Ferret B, Guidotti A, Costa E (1988): Gangliosides prevent glutamate and kianate neurotoxicity in primary neuronal cultures of neonatal rat cerebellum and cortex. Proc Natl Acad Sci 85:7351-7355

Fischer C, Hatzidimitriou G, Wlos J, Katz J, Ricaurte G (1995): Reorganization of ascending 5-HT axon projections in animals previously exposed to the recreational drug 3,4-methylenedioxymethamphetamine (MDMA, "Ecstasy"). J Neurosci 15:5476-5485

Fisher JF, Cho AK (1979): Chemical release of dopamine from striatal homogenates: Evidence for an exchange diffusion model. J Pharmacol Exp Ther 208:203-209

Fuller RW, Perry KW, Molloy BB (1975): Reversible and irreversible phases of serotonin depletion by 4-chloroamphetamine. Eur J Pharmacol 33:119-124

Giambalvo CT (1992a): Protein kinase C and dopamine transport. 1. Effects of amphetamine in vivo. Neuropharmacology 31:1201-1210

Giambalvo CT (1992b): Protein kinase C and dopamine transport. 2. Effects of amphetamine in vitro. Neuropharmacology 31:1211-1222

Gott AL, Mallon BS, Paton A, Groome N, Rumsby MG (1994): Rat brain glial cells in primary culture and subculture contain the delta, epsilon, and zeta subspecies of protein kinase $C$ as well as the conventional subspecies. Neurosci Lett 171:117-120

Gu XF, Azmitia EC (1993): Integrative transporter-mediated release from cytoplasmic and vesicular 5-hydroxytryptamine stores in cultured neurons. Eur J Pharmacol 235:51-57

Gudelsky GA, Yamamoto BK, Nash JF (1994): Potentiation of 3, 4-methylenedioxymethamphetamine-induced dopamine release and serotonin neurotoxicity by 5-HT2 agonists. Eur J Pharmacol 264:325-330

Harvey JA, McMaster SE, Yunger LM (1975): p-Chloroamphetamine: Selective neurotoxic action in the brain. Science 187:841-843

Hekmatpanah CR, Peroutka SJ (1990): 5-hydroxytryptamine uptake blockers attenuate the 5-hydroxytryptaminereleasing effect of 3,4-methyldioxymethamphetamine and related agents. Eur J Pharmacol 177:95-98

Hrdina PD, Vu TB (1993): Chronic fluoxetine treatment upregulates 5-HT uptake sites and 5-HT2 receptors in rat brain: An autoradiographic study. Synapse 14:324-331

Huff RA, Vaughan RA, Kuhar MJ, Uhl GR (1997): Phorbol esters increase dopamine transporter phosphorylation and decrease transport Vmax. J Neurochem 68:225-232

Hyde CE, Bennett BA (1994): Similar properties of fetal and adult amine transporters in the rat brain. Brain Res 646:118-123

Insel TR, Battaglia G, Johannessen JN, Marra S, DeSouza EB (1989): 3,4-methylenedioxymethamphetamine ("Ecstasy") selectively destroys brain serotonin terminals in rhesus monkeys. J Pharmacol Exp Ther 249:713-720

Johnson MP, Hoffman AJ, Nichols DE (1986): Effects of the enantiomers of MDA, MDMA, and related analogues on $[3 \mathrm{H}]$ serotonin and $[3 \mathrm{H}]$ dopamine release from superfused rat brain slices. Eur J Pharmacol 132:269-276

Johnson MP, Conarty PF, Nichols DE (1991): [3H]Monoamine releasing and inhibition properties of 3,4-methylenedioxymethamphetamine and $\mathrm{p}$-chloramphetamine analogues. Eur J Pharmacol 200:9-16

Kagaya A, Mikuni M, Kusumi I, Yamamoto H, Takahashi K (1990): Serotonin-induced acute desensitization of serotonin2 receptors in human platelets via a mechanism involving protein kinase C. J Pharmacol Exp Ther 255: 305-311 
Kendall DA, Nahorski SR (1985): 5-HT-stimulated inositol phospholipid hydrolysis in rat cerebral cortex slices: Pharmacological characterization and effects of antidepressants. J Pharmacol Exp Ther 233:473-479

Kimelberg HK (1986): Occurrence and functional significance of serotonin and catecholamine uptake by astrocytes. Biochem Pharmacol 35:2273-2281

Kokotos Leonardi ET, Azmitia EC (1994): MDMA (Ecstasy) inhibition of MAO type A and type B: Comparisons with fenfluramine and fluoxetine (Prozac). Neuropsychopharmacology 10:231-238

Kramer HK, Azmitia EC (1994): Is protein kinase C activation a key step in MDMA-induced toxicity of serotonergic neurons? CPDD Abstr 144:273

Kramer HK, Poblete JC, Azmitia EC (1995): 3,4-methylenedioxymethamphetamine ("Ecstasy") promotes the translocation of protein kinase C (PKC): Requirement of viable serotonin nerve terminals. Brain Res 680:1-8

Lowry OH, Rosebrough NJ, Farr AL, Randall RJ (1951): Protein measurement with the Folin phenol reagent. J Biol Chem 193:265-275

Malberg JE, Malis RW, Sabol KE, Seiden LS (1994): Both ketanserin and alpha-methyl-para-tyrosine may protect against MDMA neurotoxicity by producing a hypothermic response in the rat. CPDD Abstr 56:213

Manev H, Costa E, Wroblewski JT, Guidotti A (1990): Abusive stimulation of excitatory amino acid receptors: A strategy to limit neurotoxicity. FASEB 4:2789-2797

Masliah E, Yoshida K, Shimohama S, Gage FH, Saitoh T (1991): Differential expression of protein kinase C isozymes in rat glial cell cultures. Brain Res 549:106-111

Melloni E, Pontremolli S, Michetti M, Sacco O, Sparatore B, Salamino F, Horrecker BL (1985): Binding of protein kinase $C$ to neutrophil membranes in the presence of $\mathrm{Ca} 2+$ and its activation by a Ca2+-requiring proteinase. Proc Natl Acad Sci 82:6435-6439

Miller HH, Shore PA, Clarke DE (1980): In vivo monoamine oxidase inhibition by amphetamine. Biochem Pharmacol 29:1347-1354

Miller KJ, Hoffman BJ (1994): Adenosine A3 receptors regulate serotonin transport via nitric oxide and cGMP. J Biol Chem 269:27351-27356

Nash JF (1990): Ketanserin pretreatment attenuates MDMAinduced dopamine release in the striatum as measured by in vivo microdialysis. Life Sci 47:2401-2408

Nash JF, Brodkin J (1991): Microdialysis studies on 3,4-methylenedioxy-methamphetamine-induced dopamine release: Effect of dopamine uptake inhibitors. J Pharmacol Exp Ther 259:820-825

Nash JF, Arora RC, Schreiber MA, Meltzer HY (1991): Effect of 3,4-methylenedioxymethamphetamine on 3H-paroxetine binding in the frontal cortex and blood platelets of rats. Biochem Pharmacol 41:79-84

Nichols DE, Lloyd DH, Hoffman AJ, Nichols MB, Yim GK (1982): Effects of certain hallucinogenic amphetamine analogues on the release of [+3] H-serotonin from rat brain synaptosomes. J Med Chem 25:530-535

Nishizuka Y (1986): Studies and perspectives of protein kinase C. Science 233:305-312
Novotney S, Lowy MT (1995): Short-term and long-term effects of p-chloroamphetamine on hippocampal serotonin and corticosteroid receptor levels. Brain Res 684:19-25

O'Hearn E, Battaglia G, DeSouza EB, Kuhar MJ, Molliver ME (1988): Methylenedioxyamphetamine (MDA) and methylenedioxymethamphetamine (MDMA) cause selective ablation of serotonin axon terminals in forebrain: Immunocytochemical evidence for neurotoxicity. J Neurosci 8:2788-2803

Onodera H, Araki T, Kogyre K (1989): Protein kinase C activity in the rat hippocampus after forebrain ischemia: Autoradiographic analysis by 3 Hphorbol 12,13 dibutyrate. Brain Res 481:1-7

Park WP, Azmitia EC (1991): 5-HT, MDMA (Ecstasy), and nimodipine effects on 45Ca2+-uptake into rat brain synaptosomes. Ann NY Acad Sci 635:438-442

Poblete JCP, Azmitia EC (1995): Activation of glycogen phosphorylase by 3,4-methylenedioxymethamphetamine in astrocyte-rich primary glial cultures: Role of the $5-\mathrm{HT}_{2 \mathrm{~A}}$ receptor. Brain Res 680:9-16

Pranzatelli MR (1991): Regulation of 5-HT2 receptors in rat cortex. Studies with a putative selective agonist and antagonist. Biochem Pharmacol 42:1099-1105

$\mathrm{Pu}$ C, Vorhees CV (1995): Protective effects of MK-801 on methamphetamine-induced depletion of dopaminergic and serotonergic terminals and striatal astrocytic response: An immunohistochemical study. Synapse 19: 97-104

Ricaurte GA, DeLanney LE, Weiner SG, Langston JW (1988): Toxic effect of MDMA on central serotonergic neurons in the primate: Importance of route and frequency of drug administration. Brain Res 446:165-168

Rudnick G, Wall SC (1992a): The molecular mechanism of "ecstasy" [3,4-methylenedioxymethamphetamine (MDMA)]: Serotonin transporters are targets for MDMAinduced serotonin release. Proc Natl Acad Sci 89:18171821

Rudnick G, Wall SC (1992b): p-chloroamphetamine induces serotonin release through serotonin transporters. Biochem 31:6710-6718

Sanders-Bush E, Strenaka LR (1978): Immediate and longterm effects of p-chloroamphetamine on brain amines. Ann NY Acad Sci 305:208-221

Schmidt CJ (1987): Neurotoxicity of the psychedelic amphetamine, methylenedioxymethamphetamine. J Pharmacol Exp Ther 240:1-7

Schmidt CJ, Taylor VL (1987): Depression of rat brain tryptophan hydroxylase activity following the acute administration of methylenedioxymethamphetamine. Biochem Pharmacol 36:4095-4102

Schmidt CJ, Black CK, Taylor VL (1990): Antagonism of the neurotoxicity due to the single administration of methylenedioxymethamphetamine. Eur J Pharmacol 181:59-70

Schmidt CJ, Taylor VL, Abbate GM, Nieduzak TR (1991): 5-HT2 antagonists stereoselectively prevent the neurotoxicity of 3,4-methylenedioxymethamphetamine by blocking the acute stimulation of dopamine synthesis: Reversal by I-dopa. J Pharmacol Exp Ther 256:230-235

Silver PJ, Sigg EB, Moyer JA (1986): Antidepressants and protein kinases: Inhibition of $\mathrm{Ca} 2+$-regulated myosin 
phosphorylation by fluoxetine and iprindole. Eur J Pharmacol 121:65-71

Steele TD, McAnn UD, Ricaurte GA (1994): 3,4-methylenedioxymethamphetamine (MDMA, "Ecstacy"): Pharmacology and toxicology in animals and humans. Addiction 89:539-551

Wang H-Y, Friedman E (1990): Central 5-hydroxytryptamine receptor-linked protein kinase $\mathrm{C}$ translocation: A functional postsynaptic signal transduction system. Mol Pharmacol 37:75-79

Wolf M, Cuatrecasas P, Sahyoun N (1985): Interaction of pro- tein kinase $\mathrm{C}$ with membranes is regulated by $\mathrm{Ca}++$, phorbol ester, and ATP. J Biol Chem 260:15718-15722

Yang CM, Yo YL, Hsieh JT, Ong R (1994): 5-Hydroxytryptamine receptor-mediated phosphoinositide Hydrolsysis in canine cultured tracheal smooth muscle cells. $\mathrm{Br}$ J Pharmacol 111:777-786

Yau JLW, Kelly PAT, Sharkey J, Seckl JR (1994): Chronic 3,4-methylenedioxymethamphetamine administration decreases glucocorticoid and mineralocorticoid receptor, but increases 5-HT-1C receptor gene expression in the rat hippocampus. Neuroscience 61:31-40 